FILOZOFIA

Roč. 76,2021, č. 3

DOI: https://doi.org/10.31577/filozofia.2021.76.3.2

\title{
SOCIÁLNO-ETICKÉ DÔSLEDKY NEUROVYLEPŠOVANIA ${ }^{1}$
}

\author{
JANA TOMAŠOVIČOVÁ, Univerzita sv. Cyrila a Metoda v Trnave, Filozofická fakulta, Katedra \\ filozofie a aplikovanej filozofie, Trnava, SR
}

TOMAŠOVIČOVÁ, J.: Social and Ethical Consequences of Neuro-enhancement FILOZOFIA, 76, 2021, No 3, pp. $181-194$

\begin{abstract}
The paper deals with the analysis of specific social and ethical consequences of neuro-enhancement. In the first part of the paper, we will present some of the basic methods and technologies that allow to improve cognitive and emotional abilities. In the following sections, we will subsequently analyze the three most serious areas of socio-ethical problems related to the impact of neuro-enhancement on the individual and society. We will examine in more detail the threat to the principle of autonomy posed by two selected technologies used for neuroenhancement, namely the integrated neuromodulation system (closed-loop BCI) and genetic technologies. Next, we will deal with the influence of social pressure on autonomous human decision-making and with the question of whether social pressure is a sufficient reason for the unacceptability of neuro-enhancement. Finally, in relation to the numerous concerns about the deepening of social inequality as a result of the spread of enhancement practices, we will examine whether the deepening of inequality can be prevented and whether the principle of equal opportunities can be considered a sufficient criterion of equality in a given situation.
\end{abstract}

Keywords: Neuro-enhancement - Neuro-enhancement technologies - Individual autonomy - Social pressure - Equality and fairness - Principle of equality

\section{Úvod}

Technický vývoj v posledných desat'ročiach významnou mierou prispel k prehĺbeniu poznania l'udského organizmu. Možnosti nových technológií a vedeckého poznania sa natol'ko rozšrírili, že postupne prekračujú čisto terapeutické ciele a v kombinácii s odvekou túžbou človeka zdokonalit' svoje prirodzené schopnosti otvárajú priestor pre fenomén vylepšovania človeka (human enhancement). Ten patrí k popredným témam aktuálneho bioetického diskurzu. Špecifické použitie pojmu enhancement v ob-

\footnotetext{
${ }^{1}$ Za cenné poznámky a pripomienky k pôvodnej verzii textu d’akujem viacerým svojim kolegom, a taktiež anonymným recenzentom príspevku. Niektoré z nich sú pre mňa vhodným podnetom na rozvinutie témy z pohl'adu d'alších možných dôsledkov neurovylepšovania.
} 
lasti bioetiky sa spája so stupňovaním a rozširovaním fyzických, kognitívnych, emocionálnych či charakterových vlastností človeka prostredníctvom biotechnologických zásahov do zdravého organizmu (Schöne-Seifert, Stroop 2015, 249). ${ }^{2}$ Na rozdiel od tradičných humanistických foriem zdokonal'ovania, akými boli výchova, vzdelávanie či trénovanie, sa pri súčasných zámeroch vylepšovat' človeka spoliehame najmä na moderné technológie. Nejde pritom len o vzdialené vízie budúcnosti, pretože viaceré technológie sa už dnes použivajú na dosiahnutie vytýčených cielov, alebo sa nachádzajú v pokročilom štádiu výskumu. Dynamika, s akou sa vyvíjajú, preto celkom oprávnene upriamuje pozornost' na reflexiu ich možných dôsledkov na jednotlivca i na spoločnost'.

$\mathrm{V}$ príspevku upriamime pozornost' na neurovylepšovanie (neuroenhancement), teda predovšetkým na rozširovanie kognitívnych schopností človeka (cognitive enhancement) a na zlepšenie jeho emocionálnych stavov (mood enhancement), pričom budeme analyzovat' vybrané sociálno-etické dôsledky tohto fenoménu (ethics of neuroenhancement). Najskôr predstavíme niekol'ko základných prostriedkov, metód a technológií, ktoré umožňujú modifikovat' kognitívne i emocionálne schopnosti. Následne sa pri rozbore sociálno-etických dôsledkov neurovylepšovania sústredíme na tri vybrané okruhy problémov: zameriame sa na ohrozenie autonómie jednotlivca, na zvyšujúci sa sociálny tlak na zdokonal'ovanie kognitívnych i emocionálnych schopností človeka a na prehlbovanie sociálnej nerovnosti a s tým spojené problémy distributívnej spravodlivosti. Hoci sa v rámci medicíny zväčša opierame o princíp informovaného súhlasu, na základe ktorého o vážnych zásahoch do l'udského organizmu rozhoduje sám pacient, predsa možno pri podrobnej analýze neurovylepšovania, a najmä dosahu vybraných technológií, pozorovat' sproblematizovanie konceptu autonómie. Je legitímne akceptovat' metódy neurovylepšovania, ak sú v konflikte s princípom autonómie? Ked’že sa dá predpokladat, že neurovylepšovanie zvýši kognitívne a emocionálne kompetencie jeho nositel’om, čím sa zvýšia aj ich šance na spoločenské uplatnenie, možno očakávat', že sa bude stupňovat' sociálny tlak na jednotlivca, aby sa v záujme zvýšenia svojej výkonnosti podrobil neurovylepšovaniu. Ako môže ovplyvnit' rastúci sociálny tlak autonómne rozhodovanie a konanie človeka? Môže byt' tento sociálny tlak dostatočným dôvodom na neprípustnost' neurovylepšovania? Z hl'adiska očakávaných sociálno-etických dôsledkov neurovylepšovania nemožno obíst' ani obavy z prehĺbenia sociálnej nerovnosti a roztvárania sociálno-ekonomických nožníc, najmä keby neurovylepšovanie, ktoré vytvorí jeho nositel’om výhody v sút'aži, nebolo dostupné všetkým. Otázkou je, ako zabránit’ prehíbeniu sociálnej nerovnosti, a taktiež či princíp rovnosti príležitostí možno pokladat' za dostatočné kritérium na posudzovanie rovnosti v danej situácii. Analýza uvedených problémov, ktoré

${ }^{2}$ Pozri aj Birnbacher (2019, 18; 2006, 77 - 78), Merkel (2019, 50 - 51). 
patria $\mathrm{v}$ súčasnosti $\mathrm{k}$ najdiskutovanejším sociálno-etickým aspektom neurovylepšovania, bude predmetom nasledujúceho príspevku.

\section{Prostriedky, metódy a technológie neurovylepšovania}

K základným prostriedkom, metódam a technológiám, ktoré sa dajú využit' na účely neurovylepšovania, patria najmä farmakologické substancie, neurotechnologické metódy, technológie editovania génov, ako aj informačno-komunikačné technológie (Talbot, Wolf 2006, 254 -259). Psychofarmaká zasahujú do chemického prenosu informácií v centrálnej nervovej sústave a už dnes sa používajú nielen na terapeutické, ale aj na vylepšujúce účely. Ide zväčša o substancie, ktoré boli pôvodne vyvinuté na terapiu niektorých psychických ochorení (napr. depresia, poruchy pozornosti, narkolepsia a i.), v súčasnosti sú však čoraz častejšie vyhl'adávané v súvislosti s ich potenciálom zlepšit' koncentráciu a pamät', zvýšit' bdelost', prekonat' únavu či redukovat' ostýchavost' a zvýšit' sebavedomie v prípade, že sú aplikované na zdravý organizmus (Kramer 1993; 1995; President's Council on Bioethics 2009, 319 - 321). ${ }^{3}$ Riziká spojené s dlhodobým užívaním týchto substancií sú stále predmetom vedeckého skúmania.

K moderným neurotechnologickým metódam, ktoré sú založené na efektívnom prepojení l’udského mozgu s technickým zariadením, patria najmä transkraniálna magnetická stimulácia, híbková mozgová stimulácia a integrované neuromodulačné systémy (Clausen 2008, 40 - 45). Zatial' čo transkraniálna magnetická stimulácia je neinvazívna metóda, pri ktorej sa jednorazovo alebo opakovane aplikuje krátky magnetický impulz z vonkajšej strany mozgu najmä pacientom s psychickými ochoreniami, hĺbková mozgová stimulácia predstavuje invazívnu metódu, pri ktorej sa elektrické impulzy privádzajú do zvolenej časti mozgu prostredníctvom implantovaných elektród napojených na neurostimulátor (Clausen 2008, 43; Stieglitz 2008, 65). Neurostimulácia umožňuje zmiernit' problémy pri motorických ochoreniach v pokročilom štádiu, no používa sa aj pri liečbe epilepsie, obsedantno-kompulzívnej poruchy a t’ažkých foriem

\footnotetext{
${ }^{3}$ Psychiater Peter D. Kramer v knihe Listening to Prozac (1993) popísal prípadové štúdie zo svojej praxe, ktorými inicioval širokú diskusiu o etických aspektoch používania psychofarmakologických substancií mimo rámca terapie (off label use). V rámci tejto diskusie sa uvažuje najmä o zmenách osobnosti, osobnej identity, o vplyve na autentické formy správania a usudzovania u daného užívatel'a (Kramer 1993, 291), ako aj o dôsledkoch vzhl'adom na zaužívané formy sociálnej praxe, v rámci ktorej boli doteraz pocity št’astia zväčša výsledkom určitej vynaloženej námahy alebo úsilia (President's Council on Bioethics 2009, 333 - 342). Kritici farmakologického neurovylepšovania opakovane upozorňujú najmä na riziká spojené so zmenou osobnosti, ktorá sa často vyznačuje stratou autentickosti a pribúdaním pocitov sebaodcudzenia (Elliott 1998, 177 - 188). Naopak, obhajcovia neurovylepšovania sa usilujú aj prostredníctvom konkrétnych prípadov poukázat’ na to, že viacerí uživatelia (napr. ostýchaví, utiahnutí, úzkostliví) pozitívne hodnotia vplyv farmakologických prostriedkov na utváranie ich vlastného autentického ja (DeGrazia 2000, 35; Heinrichs 2019, 180 - 184).
} 
depresie. Integrované neuromodulačné systémy (closed-loop Brain-Computer Interface) zasa predstavujú technológiu, ktorá je založená na kombinácii odvádzajúcich a stimulujúcich systémov. Dokážu teda nielen zachytávat' elektrickú aktivitu z mozgu, ale pomocou napojeného technického zariadenia ju vedia aj analyzovat' a v prípade potreby vyslat' zosilnené impulzy spät' do mozgu. Tento systém regulácie s takzvaným uzavretým obvodom plní diagnostické aj terapeutické funkcie a v súčasnosti sa využíva najmä pri liečbe epilepsie rezistentnej voči liekom, avšak experimentálne sa skúma aj pri d’alších ochoreniach, napríklad pri zmierňovaní agresívneho správania (Schulze-Bonhage, Ball 2009, 35 - 49). Zároveň nemožno prehliadnut' zvyšujúci sa záujem výskumných tímov, ktoré sa snažia potenciál neurotechnologických metód zužitkovat' aj na pozitívne ovplyvňovanie a stimulovanie kognitívnych procesov (tamže, 47).

Ďalšou technológiou, o ktorej sa uvažuje ako o technológii zásadného, revolučného významu, je technológia editovania génov, pomocou ktorej možno s pomerne vel'kou presnost'ou uskutočnit' cielené zmeny v l'udskom genóme. Najmä technológia CRISPR-Cas9 poskytuje sl’ubný nástroj na cielené prepisovanie, editovanie základných stavebných častí DNA (Doudna, Sternberg 2018, 124 - 125). Zmeny genetickej informácie možno uskutočnit' bud' na úrovni somatických buniek, alebo na úrovni zárodočných buniek. Zatial' čo somatická génová terapia sa zväčša považuje za eticky akceptovatel'nú, pretože vykonaným zásahom možno predíst' budúcemu závažnému ochoreniu, ktoré by dotknutej osobe komplikovalo možnost' viest' plnohodnotný život, zmeny uskutočňované na úrovni zárodočných buniek, ktoré by sa prenášali aj na d’alšie generácie, sú hodnotené ako eticky sporné. Viacerí vedci preto vyzvali na dočasné moratórium, vzt’ahujúce sa na editovanie génov zárodočnej línie, počas ktorého sa majú zodpovedne posúdit' všetky relevantné námietky k týmto zásahom (Sýkora 2019,511 - 512). Editovanie génov je tak v súčasnosti predmetom vedeckých, medicínskych, etických i spoločenských diskusií. Výskum v tejto oblasti však pokračuje a spolu s ním sa formujú aj vízie využitia danej technológie nielen na terapeutické, ale aj na vylepšujúce účely (President's Council on Bioethics 2009, 305 - 318).

Výskumné tímy vo svete sa pokúšajú zužitkovat’ aj potenciál moderných informačno-komunikačných technológií na kognitívne vylepšovanie človeka. Zameriavajú sa pritom na vývoj biočipov či na možnosti kopírovania l’udskej mysle do externého technického zariadenia (Talbot, Wolf 2006, 256 - 257). Tieto možnosti majú zatial' skôr špekulatívny, futurologický charakter, ale rýchlost', s akou napreduje vývoj informačno-komunikačných technológií, predpokladá, že v budúcnosti sa môžu stat' realitou.

Uvedené techniky naznačujú, že vylepšovanie l’udského mozgu je do vel'kej miery možné už dnes, no v budúcnosti sa tieto príležitosti s vysokou pravdepodob- 
nost'ou budú ešte zvyšovat'. Vylepšovanie l'udskej výkonnosti môže totiž v spoločnosti zameranej na výkon predstavovat' jeden zo spôsobov, ako sa vyrovnat' s limitami a obmedzeniami nedokonalých l'udských schopností. Ked’že však ide o zásah do centrálnej nervovej sústavy, oprávnene sa posudzujú najmä riziká medicínskeho, etického a sociálneho charakteru. Reflexie týchto rizík sú dnes už pomerne rozsiahle. Týkajú sa skúmania viacerých medicínskych rizík z pohl’adu účinnosti a dlhodobých následkov, d’alej možných etických problémov, akými sú zmeny osobnosti, osobnej identity a autentickosti užívatel'a, ale aj čoraz častejšie kladených otázok pripísania zodpovednosti za konanie, ktoré je ovplyvnené technologicky a ktorého dôsledky možno len t’ǎko predvídat' (Heinrichs 2019, 155 - 189). ${ }^{4}$ V nasledujúcej časti príspevku sa však bližšie zacielime hlavne na analýzu očakávaných sociálno-etických dôsledkov daného fenoménu, pričom budeme hlbšie analyzovat' tri najčastejšie diskutované okruhy problémov: autonómiu jednotlivca, sociálny tlak a problémy rovnosti a spravodlivého prístupu. Ide o problémy, ktoré nezasahujú iba jednotlivca, ale majú dosah na širšie spoločenstvo či spoločnost', preto sa im v súčasných odborných diskusiách venuje zvýšená pozornost'.

\section{Autonómia jednotlivea}

Autonómiu jednotlivca pokladáme za základnú hodnotu liberálnej spoločnosti. Pri vymedzovaní tohto pojmu sa súčasný bioetický diskurz opiera hlavne o liberálnu tradíciu, kde sa autonómia chápe ako právo dospelej osoby viest' vlastný život a robit' dôležité rozhodnutia podla vlastných preferencií, hodnôt a životných plánov, pokial' tým nepoškodzuje iných (Mill 1995, 16; Hill 2004, 178 - 189). V danom koncepte sú podstatné dva aspekty. Jedným je oprávnenie jednotlivca rozhodovat' o vlastnom živote suverénne, teda bez nátlaku, manipulácie či donútenia. Druhým aspektom je priznat' rovnaké právo na sebaurčenie aj iným osobám a zamedzit’ tak poškodzovaniu ich práv. Otázka v našom kontexte znie, či vylepšujúce zásahy do centrálnej nervovej sústavy môžu predstavovat' ohrozenie autonómie jednotlivca? V medicínskej praxi sa otázka autonómie rieši zväčša formou informovaného súhlasu. To znamená, že jednotlivec na základe poskytnutých odborných informácií rozhoduje o uskutočnení lekárskeho zásahu do vlastného organizmu vyjadrením svojho súhlasu alebo nesúhlasu s daným zásahom. $\mathrm{Z}$ tohto

\footnotetext{
${ }^{4}$ Marco Stier problematickost' pripísania zodpovednosti za konanie v situácii, ked' je l’udský mozog ovplyvňovaný technickým zariadením, popisuje ako problém, v rámci ktorého na jednej strane nemožno vplyv neurotechnológie na konanie osoby úplne vymazat', pretože potom by osoba musela niest' zodpovednost' aj za konanie zapríčinené chybným fungovaním technológie. Na druhej strane zasa nemôže byt' konanie ani úplne pripísané vplyvu technológie, pretože tak by osoba stratila status morálneho agensa. V danej situácii sa uvažuje o oživení pojmu spoluzodpovednosti a zaradení zhotovitel'a technológie do okruhu spoluzodpovedných osôb (Stier 2009, 289 - 291; porov. Tomašovičová 2018, $159-161)$.
} 
pohl'adu sa zdá, že princíp autonómie by nemal byt' pri vylepšujúcich zásahoch porušený, ak konkrétnym praktikám predchádza informovaný súhlas dotknutej osoby.

Pozrime sa však bližšie na dva prípady možného obmedzenia osobnej autonómie v súvislosti s využitím dvoch vybraných technológií na neurovylepšovanie. Prvý prípad sa týka použitia integrovaného neuromodulačného systému (closed-loop Brain-Computer Interface), založeného na úzkej symbióze človeka a technického zariadenia, ktoré v rámci vzájomnej interakcie ovplyvňuje mentálne výkony jednotlivca. Dokáže nielen zachytit' potenciálnu elektrickú aktivitu mozgu, ale ju aj pomocou algoritmov spracovat' a vzápätí uskutočnit' stimuláciu. Algoritmy pritom pracujú v mode samostatného, takzvaného strojového učenia, čo znamená, že situáciu vyhodnocujú samostatne, bez l’udskej asistencie (Schulze-Bonhage, Ball 2009, 38 - 40). Na základe skúmania predchádzajúcich dát robia predpovede budúceho diania a navrhujú rozsah stimulácie. Pritom ich vyhodnotenie v podobe vyslaných elektrických impulzov má vplyv na rozhodovanie i konanie človeka. Je v takomto prípade ohrozená autonómia jednotlivca, ktorého výkony by boli ovplyvňované neuromodulačným systémom s uzavretým obvodom? Použitie tohto systému sa vzhl’adom na princíp autonómie stáva problematickým minimálne z dvoch dôvodov. Jedným z nich je priama stimulácia zvolených častí mozgu, ktorá sa uskutočňuje bez zapojenia kontrolného mechanizmu uživatela, akým je napríklad zmyslový aparát. To znamená, že elektrický signál je vysielaný priamo do mozgu bez toho, aby si toho bol užívatel' vedomý a aby ho mohol v prípade potreby korigovat' (porov. Merkel 2019, 75 - 78; Odorčák 2018, 449 - 457). Druhým dôvodom je skutočnost', že analyzovanie dát, predikcia diania i následná intenzita stimulácie sú v plnej kompetencii technického zariadenia, ktoré pracuje automaticky na báze samostatného učenia. Ked’že tieto analýzy a predikcie priamo vplývajú na konanie jednotlivca, uvedené dôvody možno interpretovat' ako zásah do jeho autonómie, preto treba zvážit' použitie daného systému čisto na vylepšujúce účely. To však zároveň neznamená, že je nutné automaticky vylúčit' všetky jeho možné aplikácie. Napríklad terapeutické použitie integrovaného neuromodulačného systému umožňuje pacientom s epilepsiou odvrátit' záchvat a stabilizovat' zdravotný stav, preto $\mathrm{v}$ takomto prípade môže u pacienta prevážit' úžitok $\mathrm{z}$ využitia daného zariadenia, $\mathrm{v}$ zmysle princípu zabezpečenia zdravotnej starostlivosti, nad možnými rizikami. V prípade pacientov s t’ažkým ochrnutím im zasa zabezpečuje často jedinú možnost' komunikácie s okolím (Nijboer, Kleih, Kübler 2009, 51 -62). Avšak aj pri terapeutickom použití treba dôsledne sledovat' vedl'ajšie nežiaduce účinky, akými môžu byt' napríklad poškodenie mentálnej kompetencie pacienta alebo rozvinutie agresívneho správania, ktoré sa prejavili už pri terapeutickom použití systému staršieho typu (open-loop system) (porov. Galert 2016, 104)..$^{5}$ To znamená, že

\footnotetext{
${ }^{5}$ Pozri aj Tomašovičová $(2018,137$ - 163).
} 
aj v prípadoch sl'ubného terapeutického potenciálu je namieste ustavične medicínsky i eticky zvažovat' a vyhodnocovat' mieru úžitku a rizík spojenú s integráciou technického zariadenia do l'udského mozgu, a to aj vzhl'adom na rešpektovanie princípu autonómie.

Druhý prípad obmedzenia osobnej autonómie sa týka využitia génových technológií na vylepšujúce účely, najmä na vylepšenie základných kognitívnych či emocionálnych schopností budúcej generácie, ktorej chcú rodičia vytvorit’ čo najlepšie štartovacie podmienky pre život. Relevantné námietky $\mathrm{v}$ tejto súvislosti sformulovali už viacerí autori, spomedzi nich však hlavne Joel Feinberg a Jürgen Habermas, podl'a ktorých vylepšujúce genetické zásahy, uskutočnené na druhej bytosti bez jej súhlasu, porušujú princíp autonómie (Feinberg 1980, 124 - 153; Habermas 2003, 69). Predstavujú cudzí zámer, vpísaný do genetickej informácie druhej bytosti, ktorý je problematický z viacerých dôvodov. Po prvé ho nemožno jednoduchým spôsobom zvrátit', pretože úprava sa odohráva na úrovni génov. Po druhé mu chýba legitimita, pretože cudzí zámer nie je výsledkom a akceptovaným konsenzom predchádzajúceho komunikatívneho dohovoru s dotknutou bytost'ou (Habermas 2003, 74). A po tretie porušuje morálnu požiadavku účelu osebe (Kant 2004, 57), pretože dotknutá bytost' sa stáva nástrojom plnenia predstáv iných.

S týmito námietkami možno polemizovat' poukazom na proces výchovy a socializácie, v ktorom sú deti taktiež formované podl'a preferencií a predstáv svojich rodičov, čo v mnohých prípadoch obmedzuje ich slobodu, a napriek tomu takú výchovu neodmietame (Buchanan, Brock, Daniels, Wikler 2009, 267 - 295). Avšak v procese socializácie majú deti možnost', hoci aj spätne, vzopriet' sa neakceptovatel'ným očakávaniam iných a zvolit' si vlastnú cestu, zatial' čo pri genetickom predprogramovaní takáto možnost' zvrátit' nastavený genetický program absentuje. Nevzniká tu komunikatívny priestor, ktorý by druhému dával šancu povedat' „nie“ (Habermas 2003, 74). Obmedzenie osobnej autonómie preto patrí $\mathrm{k}$ najdiskutovanejším problémom $\mathrm{v}$ debatách o prijatel'nosti genetického vylepšovania budúcej generácie, takzvaného dizajnovania detí.

Zároveň - podobne ako pri použití iných technológií, aj pri genetických modifikáciách - je nutné presnejšie diferencovat'. Napríklad pri terapeutickom upravovaní génov na somatickej úrovni, ktoré umožňuje predíst' budúcemu závažnému ochoreniu, možno odôvodnene predpokladat', že dotknutá osoba klinický zásah aspoň dodatočne odsúhlasí, čím sa minimalizuje konflikt s jej osobnou autonómiou. Výhrady súvisiace s ohrozením princípu autonómie sa preto v súčasnosti vzt’ahujú hlavne na vylepšujúce genetické zásahy, ktoré sa týkajú d’alšej generácie a ktoré sú zakázané nielen na základe dočasného moratória, ale vo viacerých krajinách aj na základe platnej legislatívy.

Uvedené príklady ohrozenia autonómie $\mathrm{v}$ dôsledku vylepšujúcich zásahov ukazujú, že isté technologické postupy môžu byt' vzhl'adom na princíp autonómie sporné. 
Patria k nim napríklad integrované neuromodulačné systémy a prenatálne genetické vylepšovanie budúceho potomstva. Zástancovia neurovylepšovania preto obracajú pozornost' skôr na neinvazívne neurotechnologické metódy alebo na farmakologické substancie, ktorých použitie sa opiera o samostatné rozhodnutie užívatel'a, čím sa predchádza možnému konfliktu s jeho autonómiou. Zároveň však prognózujú, že d’alším zdokonal'ovaním technológií bude záujem o neurovylepšovanie vel'mi pravdepodobne ešte narastat'.

\section{Sociálny tlak}

Práve v súvislosti s očakávaným rozšírením neurovylepšovania vzniká v rámci filozofického skúmania sociálno-etických dôsledkov tohto fenoménu obava z rastúceho sociálneho tlaku. Argument sociálneho tlaku vychádza z predpokladu, že vylepšenie kognitívnych a emocionálnych schopností zabezpečí jeho nositel'ovi kompetenčné výhody oproti ostatným konkurentom na trhu práce, čím sa bude stupňovat' tlak na vyššiu výkonnost' aj u tých jednotlivcov, ktorí vylepšenie z rôznych dôvodov zatial' odmietajú. Vhodné je pritom rozlísit’ implicitne vyvíjaný sociálny tlak, na ktorý má jednotlivec stále možnost' slobodne povedat' „nie“, hoci za cenu straty konkurenčnej výhody v súperení o obmedzené zdroje (napr. na trhu práce, v športe alebo vo vede) a explicitne formulovaný sociálny tlak $\mathrm{v}$ podobe výslovnej požiadavky na vylepšenie v záujme dosahovania vyšších výkonov (napr. v armáde). V danej situácii jednotlivci bud' prijmú riziko znevýhodnenia, alebo sa budú musiet' prispôsobit' a vylepšovanie podstúpit', aby odvrátili nerovné šance (Lachenmeier 2017, 69 - 108; Galert et al. 2009). Rozhodovanie pod tlakom sociálnych očakávaní však obmedzuje priestor individuálneho sebaurčenia. Otázka preto znie, či sociálny tlak môže byt' dostatočným dôvodom na etickú, prípadne právnu neprípustnost' neurovylepšovania.

Pri skúmaní tohto argumentu je vhodné posúdit', či je rozhodnutie pre neurovylepšovanie dobrovol'né alebo nedobrovol'né, pretože dobrovol'nost' je predpokladom na pripísanie zodpovednosti za konanie. Dobrovol’nost' je z právneho hl'adiska binárny pojem a umožňuje jednotlivcovi rozhodnút' sa, alebo si vybrat' $\mathrm{z}$ alternatívnych možností, ktoré má $\mathrm{k}$ dispozícii (Gutmann 2017, 35). To však neznamená, že tieto možnosti musia byt' neobmedzené alebo rovnocenné. Ani výber z oklieštených, limitovaných možností nevylučuje dobrovol'nost'. Podobne ako ju nevylučuje ani konanie či rozhodovanie, ktoré je ovplyvnené druhou osobou, len predpokladá možnost' zaujat' k danému vplyvu vlastný postoj (tamže). Sociálny tlak zväčša umožňuje jednotlivcovi vybrat' si z možností, hoci užšie vymedzených alebo limitovaných, a preto sa nedá jednoducho stotožnit' s donútením, ktoré dobrovol'nost' vylučuje (Mona 2017, 57). 
Z daného uvažovania vyplýva, že ak sociálny tlak na vylepšovanie umožňuje jednotlivcovi vybrat' si hoci aj z obmedzených možností a nemá charakter donútenia, tak nepredstavuje dostatočný dôvod na normatívny zásah v podobe zákazu vylepšovania.

Skúmanie uvedeného argumentu zároveň otvára nasledujúcu dilemu: na jednej strane sociálny tlak na vylepšovanie zužuje priestor alternatívnych možností, teda priestor na individuálne sebaurčenie. Na druhej strane však snaha eliminovat' sociálny tlak zákazom vylepšovania by bola tiež obmedzením autonómie, práva na sebaurčenie. Paternalistická ochrana je podl'a Thomasa Gutmanna možná len za cenu obmedzenia autonómie, a preto treba dôsledne zvážit jej použitie na riešenie danej situácie (Gutmann 2017, 43).

\section{Rovnost' a spravodlivý prístup}

Ďalšie problémy, o ktorých sa $\mathrm{v}$ rámci neurovylepšovania diskutuje, sa týkajú rovnosti a spravodlivého prístupu. Východisková situácia sa opät' opiera o predpoklad, že kognitívne či emocionálne vylepšenie umožní jeho nositelovi rast kompetencií, čím sa zvýšia jeho šance $\mathrm{v}$ sút'aži o pracovné príležitosti. Ked’že vylepšovanie by na rozdiel od terapeutických výkonov nemalo byt' hradené zo zdrojov verejného zdravotného poistenia, ktoré sú primárne určené na pokrytie nákladov za liečbu a ošetrenie chorôb, možno predpokladat', že nebude rovnako dostupné pre všetkých. Sociálne slabšie vrstvy obyvatel'stva, ktoré sú už teraz znevýhodnené, si ho nebudú môct' dovolit', čím sa zúži ich prístup k mnohým príležitostiam. Preto rastú obavy z prehĺbenia sociálnej nerovnosti a roztvárania sociálno-ekonomických nožníc.

V reakcii na túto situáciu sa vyprofilovalo niekol'ko postojov. Obhajcovia vylepšovania poukazujú na skutočnost', že už dnes akceptujeme vzdelávanie na súkromných školách a doplnkových kurzoch, ktoré si môžu dovolit' len deti dobre situovaných rodičov, pričom sa takýmto kvalitatívne vyšším typom vzdelávania významne rozširujú kognitívne schopnosti detí, a tým sa zlepšujú aj ich východiskové pozície pre d'alšie uplatnenie (Caplan 2009, 165 - 168). Nerovnost' v podobe nerovného prístupu k nadobúdaniu kognitívnych schopností je teda v spoločnosti prítomná už dnes, preto podl’a Arthura Caplana nie je zásadný rozdiel medzi „vylepšovaním“ získaným formou exkluzívneho súkromného vzdelávania a technickým neurovylepšovaním (tamže). Ak napriek nerovnému prístupu prvé akceptujeme, prečo máme druhé pre nerovný prístup diskvalifikovat? Možné znevýhodnenie sociálne slabších vrstiev nie je podla neho dôvodom na zákaz či obmedzenie vylepšovania, ale skôr podnetom na korigovanie daného vývoja a jeho dôsledkov na znevýhodnených. Naproti tomu kritici neurovylepšovania namietajú, že pokial' v spoločnosti nad’alej zaznamenávame 
problémy s nastavením dobre fungujúceho sociálneho systému, nemali by sme zavádzat' nové nástroje, pri ktorých už vopred predpokladáme, že budú jestvujúce nerovnosti ešte zväššovat' (Galert et al. 2009, 8; porov. aj Doležal 2015, 145).

Pozrime sa na tento problém z pohl'adu ohrozenia rovnosti príležitostí, o ktorom sa v danej súvislosti azda najčastejšie diskutuje. Ide pritom najmä o férovú rovnost' príležitostí, ktorá podl'a Rawlsovej teórie spravodlivosti „,vyžaduje nielen to, aby boli verejné úrady či spoločenské pozície prístupné vo formálnom zmysle, ale aby všetci mali férovú šancu ich zastávat"“ (Rawls 2007, 79). To znamená, že nestačí len formálne deklarovat' rovnaké práva na spoločenské pozície, ale treba férovo zabezpečit' ich dostupnost'. Pritom treba zohl'adnit' aj faktory, ktoré ovplyvňujú rovnost' príležitostí a vstupujú do hry ako jej predpoklady. Tieto faktory sú podla Rawlsa najmä sociálneho a prirodzeného charakteru. Ide o sociálny pôvod a status rodiny, $\mathrm{v}$ ktorej vyrastáme, a o genetické predpoklady, ktoré sa prejavujú rôznost'ou talentov a fyzickej kondície (Rawls 2007, 95). Tieto faktory Rawls pokladá za morálne náhodné, a to z toho dôvodu, že žiadny jednotlivec sa o ne nezaslúžil, ani ich nezavinil. ${ }^{6}$ Ked’že však majú tendenciu spôsobit' problematické nerovnosti aj v dobre usporiadanej spoločnosti, nemožno ich ignorovat', ale treba zaviest' systém regulácie, ktorý pomôže eliminovat' prírodnú lotériu (Rawls 2007, 96).

Ak do tejto situácie nastavovania pravidiel spravodlivého fungovania spoločnosti vstúpi neurovylepšovanie, ktoré predstavuje technologickú alebo farmakologickú modifikáciu prirodzených biologických či genetických dispozícií, musíme s ním počítat' ako $\mathrm{s}$ faktorom, ktorý bude reálne ovplyvňovat' rovnost' príležitostí. Možná podpora zo strany štátu, ktorá by zmierňovala nerovný prístup k neurovylepšovaniu, podobne ako je to napríklad pri vyrovnávaní šancí na vzdelanie, však v tomto prípade naráža na jeden z pilierov liberálnej teórie, ktorým je neutralita štátu vo vztahu k rôznym individuálnym a parciálnym predstavám a koncepciám dobrého života. S neutralitou by mohla byt' zlučitel’ná len podpora takého dobra, ktoré je všeobecne potrebné na to, aby sa l'udia ako členovia spoločnosti mohli primerane rozvíjat' a realizovat' svoje životné plány. Rawls takéto dobrá nazýva primárne dobrá, ktoré by mali byt' distribuované všetkým (Rawls 2007, 98 - 100). V reakcii na novovzniknutú situáciu a zároveň analogicky k Rawlsovej idei „sociálnych“ primárnych dobier tím autorov v zložení Buchanan, Brock, Daniels a Wikler vypracoval argument, podl'a ktorého kognitívne schopnosti človeka možno pokladat' za „prirodzené“ primárne

\footnotetext{
${ }^{6}$ „Naozaj si l'udia myslia, že si (morálne) zaslúžia, aby sa narodili viac obdarení než ostatní?“ (Rawls 2007, 122). Distribúcia vrodených schopností je podl’a Rawlsa nezaslúžená, pretože „morálne zásluhy vždy zahŕňajú nejaké svedomité úsilie vôle alebo niečo intencionálne či dobrovol’ne vykonané“" (Rawls 2007, 122, pozn. 42).
} 
dobro, pretože sú potrebné nielen na realizáciu individuálnych predstáv a individuálneho životného plánu, ale sú dôležité na realizáciu prakticky každého životného plánu (Buchanan et al. 2009, 278 - 281). Ich strata či nedostatok zároveň ohrozujú takmer všetky životné projekty. Kognitívne schopnosti majú charakter všeobecne užitočných prostriedkov, teda prostriedkov potrebných na každý účel. Preto podl’a týchto autorov možno $\mathrm{v}$ prípade potreby podporit' zvyšovanie kognitívnych schopností prostredníctvom neurovylepšovania vhodne nastaveným sociálnym programom, čím by sa zároveň regulovali a vyrovnávali aj štartovacie príležitosti. Dokonca ak akceptujeme Rawlsovu tézu, že prirodzené genetické dispozície nie sú morálne zaslúžené, pretože nie sú výsledkom individuálneho pričinenia, možno podporou vylepšovania menej talentovaných korigovat' vplyv prírodnej lotérie. Tým by sa téza o roztváraní sociálno-ekonomických nožníc po spustení neurovylepšovania nemusela naplnit’. Zabránilo by jej „nie obmedzenie privilegovaných, ale podpora znevýhodnených“ (Galert et al. 2009, 8). ${ }^{7}$

K naznačenej argumentácii treba uviest' niekol'ko kritických poznámok. Po prvé, férovú rovnost' príležitostí sa nám nedarí plne zabezpečit' ani v súčasných podmienkach, ked' tolerujeme výrazné príjmové rozdiely a s tým sa zvyšujúce šance na výhodnejšie spoločenské uplatnenie určitých jednotlivcov. Preto je opodstatnená a vzhladom na celkové fungovanie spoločnosti plne legitímna zvýšená opatrnost' pri zavádzaní nových techník, najmä v súvislosti s potenciálnymi rizikami prehlbovania nerovnosti. To, prirodzene, nie je principiálny dôvod na obmedzenie výskumu $\mathrm{v}$ oblasti neurovylepšovania, ale je to dobrý dôvod na pozorné preskúmanie jeho možných dôsledkov. Po druhé nemožno obíst' skutočnost', že princíp rovnosti príležitostí ako taký má určité limity. Dostatočne nezohl'adňuje tých, ktorí nie sú schopní uchopit' a využit' rovnost' príležitostí pre rôzne obmedzenia a postihnutia, za ktoré sami nemôžu. Zdravotne znevýhodnení l’udia so špeciálnymi potrebami vyžadujú garanciu aj špeciálnych príležitostí, aby mohli viest' hodnotný a dôstojný život. ${ }^{8}$ Po tretie, princíp rovnosti príležitostí pravdepodobne nebude dostatočným kritériom rovnosti ani pre tých, ktorí vylepšovanie z rôznych dôvodov odmietnu. Riziká ich možnej diskriminácie a s tým spojené potenciálne zdroje napätia $v$ spoločnosti by sme nemali podcenit', skôr by mali byt' výzvou na hl'adanie účinných nástrojov na reguláciu možných nerovností spôsobených neurovylepšovaním.

\footnotetext{
${ }^{7}$ Porov. tiež Sýkora, Matějková $(2011,255$ - 267).

${ }^{8}$ Namiesto princípu rovnosti príležitostí autori Amartya Sen a Martha C. Nussbaumová navrhujú prístup zameraný na spôsobilosti. V ňom sa snažia zohl'adňovat' a rešpektovat' rozmanité formy l'udského života, pričom sa opierajú o ideu dôstojnosti každého jedného človeka. Usilujú sa o zaistenie reálnych podmienok na uplatnenie slobodnej vol'by každého jednotlivca. Na Slovensku sa tomuto prístupu zameranému na spôsobilosti bližšie venuje Z. Palovičová (2018, 27 - 36).
} 


\section{Záver}

Zo súčasného vývoja $\mathrm{v}$ oblasti neurovylepšovania vyplýva, že narastajúce poznanie v oblasti neurovied a neurotechnológií nám neumožňuje iba odkrývat' a popisovat' základné procesy fungovania l'udského mozgu, ale ich aj modifikovat'. Je pritom dôležité, že v rámci tohto diskurzu sa pozornost' sústred'uje okrem výskumu aj na včasné identifikovanie možných negatívnych či sporných následkov pre jednotlivca i pre spoločnost'. Zo skúmania sociálno-etických dôsledkov neurovylepšovania sa najproblematickejším stáva obmedzenie princípu autonómie v prípade použitia neuromodulačného systému s uzavretým obvodom a v prípade aplikácie génových technológií na vylepšovanie schopností druhých bytostí. Z hl'adiska očakávaného prehíbenia sociálnej nerovnosti zostáva otvorená otázka nastavenia vhodného kritéria na posudzovanie rovnosti, pretože podl’a predchádzajúcej analýzy princíp rovnosti príležitostí dostatočne nezohl'adňuje rozmanité formy l'udskej diverzity.

Predložené skúmanie zároveň potvrdzuje, že súčasné biovedecké poznanie sa podiel’a na formovaní spoločenského vývoja. Mení charakter spoločnosti, ovplyvňuje jej sociálne i politické mechanizmy, a preto treba reflektovat' zmeny hodnôt či sociálnych praktík, ktoré nové poznanie so sebou prináša. Vzhl’adom na túto skutočnost' je dôležité, že súčast'ou posudzovania takého komplexného fenoménu, akým je neurovylepšovanie, sa stáva okrem preverovania medicínskych a etických rizík aj hodnotenie jeho možných sociálnych dôsledkov a že táto diskusia nad’alej pokračuje.

\section{Literatúra}

BIRNBACHER, D. (2006): Bioethik zwischen Natur und Interesse. Frankfurt am Main: Suhrkamp. BIRNBACHER, D. (2019): Neuroenhancement - eine ethische Sicht. In: Viertbauer, K. - Kögerler, R. (eds.): Neuroenhancement. Die philosophische Debatte. Berlin: Suhrkamp Verlag, $18-42$.

BUCHANAN, A., BROCK, D. W., DANIELS, N., WIKLER, D. (2009): Warum nicht das Beste? In: Schöne-Seifert, B. - Talbot, D. (eds.): Enhancement. Die ethische Debatte. Paderborn: Mentis Verlag, $267-294$.

CAPLAN, A. L. (2009): Ist besser das Beste? Ein renommierter Ethiker plädiert für Enhancement des Gehirns. In: Schöne-Seifert, B. - Talbot, D. (eds.): Enhancement. Die ethische Debatte. Paderborn: Mentis Verlag, $165-168$.

CLAUSEN, J. (2008): Gehirn-Computer-Schnittstellen: Anthropologisch-ethische Aspekte moderner Neurotechnologien. In: Clausen, J. - Müller, O. - Maio, G. (eds.): Die „Natur des Menschen “ in Neurowissenschaft und Neuroethik. Würzburg: Königshausen \& Neumann Verlag, 39 - 58.

DeGRAZIA, D. (2000): Prozac, Enhancement, and Self-Creation. Hastings Center Report, 30 (2), 34 - 40. DOI: https://doi.org/10.2307/3528313

DOLEŽAL, A. (2015): Právo a jeho regulační role v oblasti enhancement. In: Payne, J. et al.: Dobrý, nebo lepši život? Human enhancement. Praha: Ústav státu a práva AV ČR, 139 - 156.

DOUDNA, J. A., STERNBERG, S. H. (2018): Trhlina v stvorení. Úprava génov a nepredstavitelná moc k riadeniu evolúcie. Preložil J. Dulla. Bratislava: Citadella.

ELLIOTT, C. (1998): The Tyranny of Happiness: Ethics and Cosmetic Psychopharmacology. In: Parens, E. (ed.): Enhancing Human Traits. Ethical and Social Implications. Washington, D. C.: Georgetown University Press, 177 - 188. 
FEINBERG, J. (1980): The Child's Right to an Open Future. In: Aiken, W. - LaFollette, H. (eds.): Whose Child? Children's Rights, Parental Authority, and State Power. Totowa - NJ: Rowman \& Littlefield, $124-153$.

GALERT, T. (2016): Philosophische Aspekte der tiefen Hirnstimulation. In: Sturma, D. - Lanzerath, D. (eds.): Tiefe Hirnstimulation. Neurologische, psychiatrische und philosophische Aspekte. Freiburg, München: Karl Alber Verlag, 61 - 197.

GALERT, T. et al. (2009): Das optimierte Gehirn. Gehirn\&Geist 11. Dostupné na: https://www.spektrum.de/sixcms/media.php/976/Gehirn_und_Geist_Memorandum.pdf (Navštívené: 3. 3. 2020).

GUTMANN, T. (2017): Perfektionierungszwang? Autonomie und Freiwilligkeit in den Bereichen pränataler Diagnostik und neurologischen Enhancements. In: Brudermüller, G. - Seelmann, K. (eds.): Erzwungene Selbstverbesserung? Würzburg: Königshausen \& Neumann Verlag, 31 - 52.

HABERMAS, J. (2003): Budoucnost lidské přirozenosti. Na cestě k liberální eugenice? Preložila A Bakešová. Praha: Filosofia.

HEINRICHS, J.-H. (2019): Neuroethik. Berlin: J. B. Metzler Verlag.

HILL, T. E. Jr. (2004): Die Bedeutung der Autonomie. In: Ameriks, K. - Sturma, D. (eds.): Kants Ethik. Paderborn: Mentis Verlag, 178 - 189.

KANT, I. (2004): Základy metafyziky mravov. Preložila P. Elexová. Bratislava: Kalligram.

KRAMER, P. D. (1993): Listening to Prozac: A Psychiatrist Explores Antidepressant Drugs and the Remaking of the Self. New York: Viking.

KRAMER, P. D. (1995): Glück auf Rezept. Der unheimliche Erfolg der Glückspille Fluctin. München: Kösel Verlag.

LACHENMEIER, M. (2017): Rechtlicher Übersetzungsversuch des bioethischen Arguments des sozialen Drucks. In: Brudermüller, G. - Seelmann, K. (eds.): Erzwungene Selbstverbesserung? Würzburg: Königshausen \& Neumann Verlag, 69 - 108.

MERKEL, R. (2019): Neuroenhancement, Autonomie und das Recht auf mentale Selbstbestimmung. In: Viertbauer, K. - Kögerler, R. (eds.): Neuroenhancement. Die philosophische Debatte. Berlin: Suhrkamp Verlag, $43-88$.

MILL, J. S. (1995): O slobode. Preložil E. Višňovský. Bratislava: Iris.

MONA, M. (2017): Optionen als Zwang? Autonomie und gesellschaftlicher Druck im Kontext von Human Enhancement. In: Brudermüller, G. - Seelmann, K. (eds.): Erzwungene Selbstverbesserung? Würzburg: Königshausen \& Neumann Verlag, 53 - 67.

NIJBOER, F., KLEIB, S., KÜBLER, A. (2009): Gehirn-Computer-Schnittstellen für schwerstgelähmte Menschen. In: Müller, O. - Clausen, J. - Maio, G. (eds.): Das technisierte Gehirn. Neurotechnologien als Herausforderung für Ethik und Anthropologie. Paderborn: Mentis Verlag, 51 - 62.

ODORČÁK, J. (2018): Neuroadministratívne zariadenia a autonómia subjektu. Filozofia, 73 (6), 449 - 457.

PALOVIČOVÁ, Z. (2018): Rola individuálnej zodpovednosti v liberálnych teóriách spravodlivosti. In: Smreková, D. (ed.): Podoby zodpovednosti. Filozofické reflexie o aktuálnych spoločenských problémoch. Bratislava: Iris, $11-38$.

PRESIDENT'S COUNCIL ON BIOETHICS (2009): Bessere Kinder - Genetisches Enhancement: Ethische Analyse. In: Schöne-Seifert, B. - Talbot, D. (eds.): Enhancement. Die ethische Debatte. Paderborn: Mentis Verlag, 305 - 318.

PRESIDENT'S COUNCIL ON BIOETHICS (2009): Bessere Kinder - Enhancement mit psychotropen Medikamenten. In: Schöne-Seifert, B. - Talbot, D. (eds.): Enhancement. Die ethische Debatte. Paderborn: Mentis Verlag, 319 - 344.

RAWLS, J. (2007): Spravodlivost' ako férovost'. Preložil R. Cedzo. Bratislava: Kalligram.

SCHULZE-BONHAGE, A., BALL, T. (2009): Entwicklung und Einsatzmöglichkeiten von Brain-Machine-Interfaces bei Epilepsiepatienten. In: Müller, O. - Clausen, J. - Maio, G. (eds.): Das technisierte Gehirn. Neurotechnologien als Herausforderung für Ethik und Anthropologie. Paderborn: Mentis Verlag, $35-49$.

SCHÖNE-SEIFERT, B., STROOP, B. (2015): Enhancement. In: Sturma, D. - Heinrichs, B. (eds.): Handbuch Bioethik. Stuttgart, Weimar: J. B. Metzler Verlag, 249 - 254. 
STIEGLITZ, T. (2008): Neuroprothesen als Schnittstelle zum peripheren und zentralen Nervensystem: Ein- und Aussichten aus dem Blickwinkel der biomedizinischen Technik. In: Clausen, J. - Müller, O. - Maio, G. (eds.): Die „Natur des Menschen“ in Neurowissenschaft und Neuroethik. Würzburg: Königshausen \& Neumann Verlag, 59 - 77.

STIER, M. (2009): Das Handeln in den Zeiten der Neurotechnologie. Von der Technisierung des Gehirns zur Technisierung der Verantwortung. In: Müller, O. - Clausen, J. - Maio, G. (eds.): Das technisierte Gehirn. Neurotechnologien als Herausforderung für Ethik und Anthropologie. Paderborn: Mentis Verlag, 273 - 297.

SÝKORA, P. (2019): K posthumánnemu človeku prostredníctvom editovania génov pre kognitívne schopnosti. Filozofia, 74 (7), 511 - 529. DOI: https://doi.org/10.31577/filozofia.2019.74.7.1

SÝKORA, P., MATĚJKOVÁ, E. (2011): Kognitívne vylepšovanie človeka, evolúcia a etika. In: Kelemen, J. - Kvasnička, V. - Pospíchal, J. (eds.): Kognice a umělý život XI. Opava: Slezská univerzita, $255-267$.

TALBOT, D., WOLF, J. (2006): Dem Gehirn auf die Sprünge helfen. Eine ethische Betrachtung zur Steigerung kognitiver und emotionaler Fähigkeiten durch Neuro-Enhancement. In: Ach, J. S. Pollmann, A. (eds.): No body is perfect. Baumaßnahmen am menschlichen Körper - Bioethische und ästhetische Aufrisse. Bielefeld: Transcript Verlag, 253 - 278.

TOMAŠOVIČOVÁ, J. (2018): Problém autonómie a zodpovednosti v kontexte moderných neurotechnológií. In: Smreková, D. (ed.): Podoby zodpovednosti: filozofické reflexie o aktuálnych spoločenských problémoch. Bratislava: Iris, 137 - 163.

Táto práca bola podporená Agentúrou na podporu výskumu a vývoja na základe zmluvy APVV-170064 v rámci projektu Analýza multidimenzionálnej podoby trans- a posthumanizmu.

Jana Tomašovičová

Univerzita sv. Cyrila a Metoda v Trnave

Filozofická fakulta

Katedra filozofie a aplikovanej filozofie

Námestie J. Herdu 2

91701 Trnava

Slovenská republika

e-mail: jana.tomasovicova@ucm.sk

ORCID: https://orcid.org/0000-0002-4103-4608 